\title{
Current Trends of Brazilian Research in Chronic Diseases Related to Elderly People: a Bibliometric Study
}

\author{
Terezinha Nunes da Silva', Ana Mabel Sulpino Felisberto', \\ Maria das Graças Miguel Duarte ${ }^{2}$, \\ Maria Lucrecia Aquino Gouveia², \\ Ana Karina Moreira de Vasconcelos ${ }^{3}$, \\ Ana Zuli Vidal Moreira de Freitas ${ }^{3}$, \\ Ana Karênina de Freitas Jordão do Amaral ${ }^{4}$, \\ Greicy Kelly Gouveia Dias Bittencourt ${ }^{5}$, Valeria Peixoto Bezerra ${ }^{6}$, \\ Maria Adelaide Silva Paredes Moreira7, Antonia Oliveira Silva ${ }^{8}$
}

\section{Abstract}

This article aims to analyze the national scientific production on chronic diseases related to elderly, published in the last five years in the LILACS database, using the following keywords: elderly; aging; senility; chronic diseases; Alzheimer; dementias. This is a descriptive study, with bibliometric approach. Of the 1,255 units found, 50 were selected and analyzed after applying the inclusion criteria. Most publications on chronic disease were identified in 2011; the degree of doctor was predominant among the authors; the most commonly used mode of study was original papers; the most common area of knowledge is multidisciplinary; among data collection instruments, the questionnaire was the most frequent; the magazine with most papers was the Brazilian Journal of Geriatrics and Gerontology; elderly were the most predominant group among the participants investigated; the study region and link of the most highlighted author was the southeast region. It is noteworthy that scientific production on chronic diseases related to elderly people in Brazil is still in its infancy, suggesting the need for more research, particularly in the context of health promotion and prevention of disabilities that allow guidance to managers and health professionals staff.
1 Master's degree student in Gerontology at the Federal University of Paraiba, João Pessoa, Paraíba, Brazil

2 Master's degree student in Gerontology at the Federal University of Paraiba, João Pessoa, Paraíba, Brazil.

3 Odontologist. Member of International Group of Studies and Research in aging and social representations.

$4 \mathrm{PhD}$ student in Nursing/Adult and Elderly Health, Professor, Department of Speech Therapy, UFPB, João Pessoa, Paraíba, Brazil.

5 Federal University of Paraíba, João Pessoa, Paraíba, Brazil.

6 Nurse. Doctor. Professor of undergraduate degree in Nursing from Federal University of Paraíba.

7 Professor, Department of Speech Therapy, UFPB, João Pessoa, Paraíba, Brazil.

$8 \mathrm{PhD}$. Professor at the Federal University of Paraíba, João Pessoa, Paraíba, Brazil.

Contact information:

Ana Mabel Sulpino Felisberto.

Đakfjafono@hotmail.com

\section{Keywords}

Elderly; Chronic Diseases; Public Health; Research; Bibliometrics; Brazil. 


\section{Introduction}

Brazil is experiencing a significant change in the population profile; the result of a process of demographic transition, mainly due to the progressive aging of the population unleashing a significant increase in the number of individuals aged 60 or more in the country. IBGE data for 2011 shows that Brazil is aging rapidly, reaching 20,590,599 of elderly, or approximately $10.8 \%$ of the total population. [1, 2]

In this scenario of aging and longevity, chronic diseases are progressing and has attracted the attention of the current health system, which gives priority to meet the health needs of citizens and, as such, must operate in full accordance with the state of health of users.

It is understood as chronic diseases, according to the World Health Organization (WHO), such that are caused mainly by irreversible pathophysiological changes presented for extended time, producing residual disability and requiring treatment and specialized care for rehabilitation. We emphasize the implementation of networks of health care as a proposal to organize and integrate services into integrated systems that can respond effectively, efficiency, safety, with quality and equity, the health conditions of the Brazilian population. [3,4]

It is important to think over the economic impact that chronic diseases lead to the country in relation to expenditure of health services and the costs arising from absenteeism, retirement and death of the economically active population. It is estimated that by 2025, Brazil will have more than $30 \mathrm{mi}-$ llion people aged 60 or more, and most of them will have at least one disease. Therefore, to define the profile and evaluating statistics of chronicities in the elderly can serve as a model to develop more effective health promotion and disease prevention strategies. $[5,6]$

On the impact and consequences that the rapid Brazilian population aging presents, promoting a fundamental change in the pattern of morbidity and mortality, it was created Decree No. 483 of April 1, 2014, which deals with the health care for people with chronic diseases, establishing guidelines for the organization of their care lines. [4, 7]

In this regard, it is worth highlighting the importance of the studies that allows to bring reflection and revolutionary proposals on the subject, presenting possibilities of new paradigms for the health care of the elderly, respecting their uniqueness.

This study arose from the search for theoretical content for a seminar of the discipline of health policies in the health care of the elderly, so that they aroused the interest of going beyond the inclusive focus exhibited in the classroom and sent to an expansion of knowledge for that necessary and emerging topic.

Among the contributions that this work can offer, it must be stressed the identification of relationships and/or subjects covered in the context of health care of the elderly, as well as the detection of possible thematic gaps still unexplored.

Given the above, considering the relevance of the discussion on the topic for health professionals and researchers, we have tried in this research, answer the following question: What is the trend in the scientific literature about chronic diseases that are prevalent in elderly people in the past five years? In this perspective, this study aimed to identify the Brazilian scientific literature about chronic diseases related to elderly at the set time.

\section{Method}

This was a descriptive study, with bibliometric approach, conducted through analysis of online articles available in LILACS database, from the Virtual Health Library (VHL).

Bibliometrics responses to the difficult and necessary task of measuring, characterize and analyze science, it means, to assess the results of intellectual activity of researchers and scholars who have presented their researches in different ways. In Brazil, 
this scientific method of research has consolidated, either as an object of study or as a research technique, with diffusion in different areas of knowledge about methods and useful results to analyze specific aspects. [8, 9]

The search period included articles published between 2011 and 2015, with the collection in April 2016. Initially were identified 1,255 articles, considering the following filters: articles published in full text and in Portuguese; available in its entirety on the Internet; country of origin: Brazil; LILACS as data base; published in the period 2011-2015; with affiliation to: Brazil.

As criteria for inclusion we chose articles that presented the following descriptors previously defined as keywords of the summaries: elderly; aging; senility; chronic diseases; Alzheimer disease; dementias. And we defined as exclusions criteria: repeated publications or manuscripts and letters to the editor, dissertations, theses, monographs, books, book chapters, manuals and abstracts. Then the articles were refined by checking the keywords and selected those that mentions at least two descriptors defined in the pre-established criteria as search criteria.
From this we made an analytical reading of the article summaries, using a structured questionnaire for the data collection, which contains the following variables: year of publication; the degree of the first author; article type, area of knowledge; instrument and technique of data collection; journals; group participating in the research; state/region of the collecting and linking of the first author.

When all the information was not found in the summary, we consulted the method and the conclusion of the article in order to complete all data. Those relating to the degree of the first author were collected directly in the articles or by consulting the Lattes curriculum whenever necessary.

The extracted data were recorded and organized in a tool with format of an Excel $₫$ spreadsheet, built from the established variables. For data analysis we used the descriptive method of variables and held discussions with authors whose production was significant for the study. The presentation of the results was performed by simple descriptive statistics (absolute and percentage frequency).

Then the methodology design of this study (Figure 1) is presented.

Figure 1: Conceptual map of the method.

Guiding question: Wiche are the current trends of Brazilian researche about chronic deseases related to elderly searched in

Key words

Elderly People, Aging, Senelity, Dementias, Chronic Diseases, Alzheimer

nclusion Criteria, Articles Contraining Ar Least Two PreDefined Key Words In Search Criteria

were selected

$$
50 \text { articles } \quad \begin{gathered}
\text { were } \\
\text { organized }
\end{gathered}
$$
50 articles $\quad \begin{gathered}\text { were } \\ \text { organized }\end{gathered}$

\section{Database: LILACS}

were identified
Article, Complete Text, Portuguese, Avaiable On Line, Oringin Country, Brazil, Years: 2011-2015, Membership Country, Brazil

1255 article on May 2016

were established $<$

\section{where established}

Exclusion Criteria, Repeated Publications, Letters To The Editor, Books, Theses, Dissertations, Monographs, Manuals, Abstracts Excell
spreadsheet $\begin{gathered}\text { were } \\ \text { analized }\end{gathered}$ 


\section{Results}

1,255 articles were identified from the selected descriptors and, with the use of the exclusion criteria, were eliminated 1,205 articles. Therefore, the study sample included 50 articles grouped for analysis and that met all the criteria previously established. Calculations of variables and the construction of graphs and tables were made, seeking greater visibility of the results.

As for the choice of the database for this study, LILACS was chosen, because it includes publications in Latin America and the Caribbean, and includes the scientific production in Health Sciences published in the countries of the region since 1982, considered the most prestigious in health, available in three languages: Portuguese, Spanish and English. [10]

It shall be noticed that the first three years of study, there was an increase in publications, with its peak in 2011, followed by a significant decrease in 2014, which later presented a recovery in the publications index (Figure 2).

Regarding the assessment of the first author of the articles, researchers from different levels of knowledge were identified. It is worth noting the important representation of $\mathrm{PhD}$ level or doctoral students, followed by the degree, under degree and specialization. It shall be noticed a high interest of doctoral researchers and graduate students in this issue, as well as a lower concentration of discussion of this topic in the specializations (Figure 3).

Regarding the form of articles, we identify the significant predominance in producing original scientific article regarding to the reviews (Figure 4). This result reveals information found in the database with restricted extension, indicating the need to carry out an extensive study on the subject.

Given the area of knowledge of the authors of the selected research, it highlights health care, with multidisciplinary domain, followed by nursing and medicine, which assume higher rates in the ranking of this study (Figure 5).

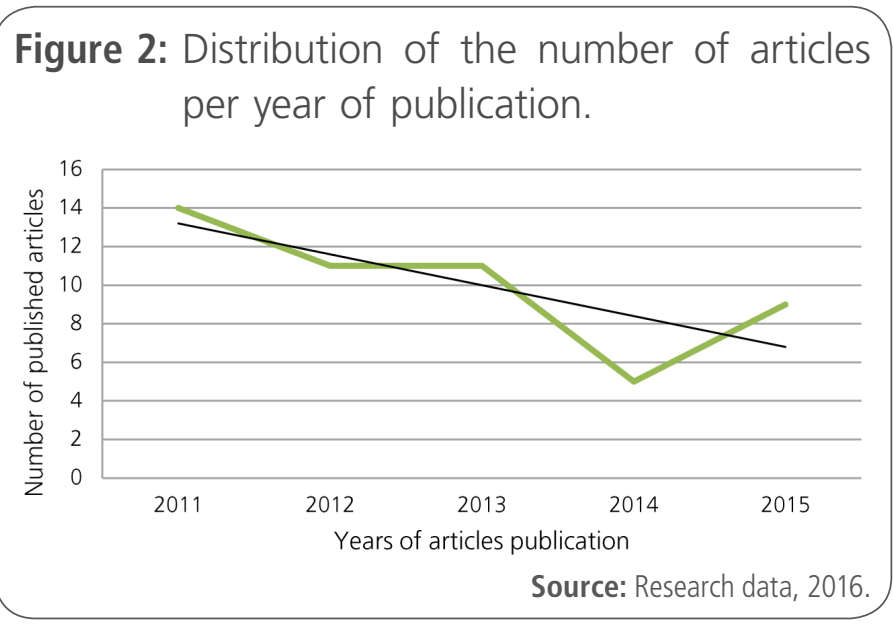

Figure 3: Distribution of the degree of the first author of the articles published between 2011-2015.

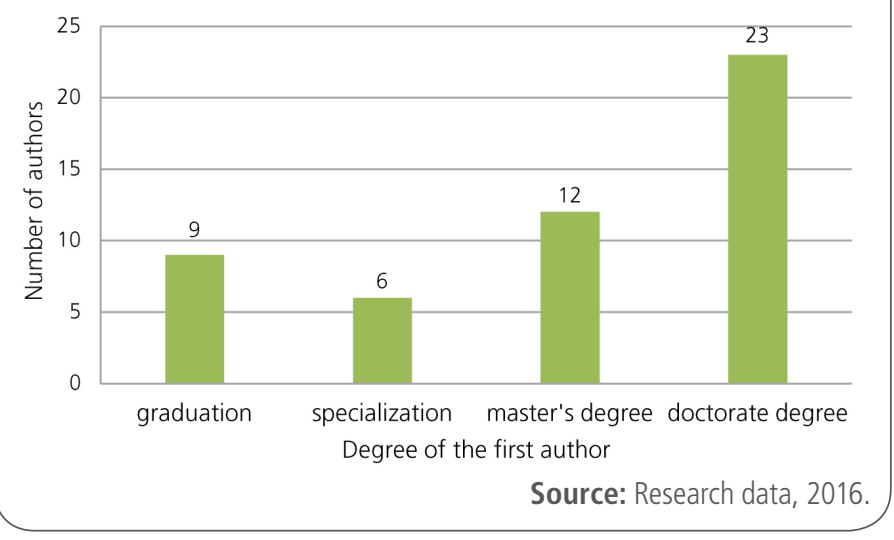

Figure 4: Distribution of the type of articles published in journals of the sample, 20112015.

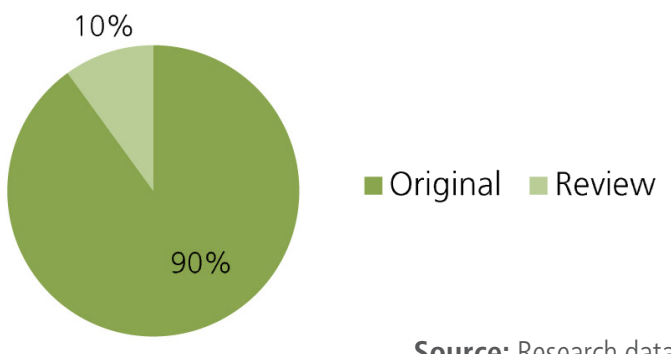

Source: Research data, 2016.

Regarding the instrument and technique of data collection of articles, it highlights the prevalence of questionnaire followed by interviews. Together, these techniques constitute the majority (70\%) of the tools used in the articles under study. Review 
Figure 5: Distribution by area of knowledge of the first author of the articles published in the period 2011-2015.

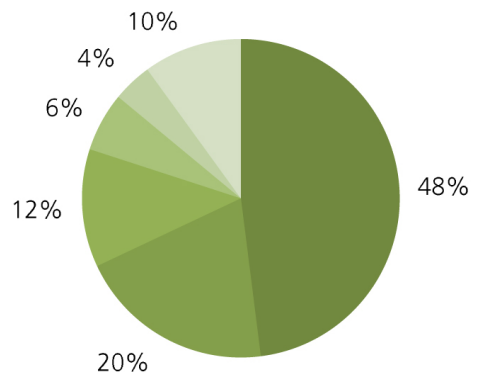

- Multidisciplinary

nursing

Medicine

Nutrition

Fisioteraphy

- Outhers

Source: Research data, 2016.

Figure 6: Distribution of instruments and data collection technique of articles published between 2011-2015.

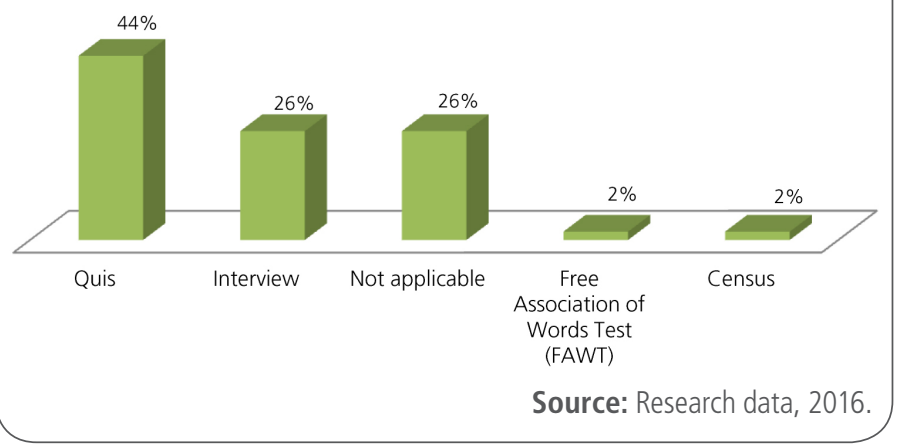

articles, of which empirical material was collected in databases or not specified computerized environment, were classified as "not applicable". The test of Free Association of Words (Teste de Associação Livre de Palavras: TALP) and the census of the Brazilian Institute of Geography and Statistics for 2010 (IBGE) were also identified as collection instruments, although to a lesser extent. (Figure 6).

With regarding to the journals, it can be observed that those who most published about the pathological chronic illness of elderly people were the Brazilian Journal of Geriatrics and Gerontology; the Magazine Science and Public Health and the Journal of Research in critical care online. Magazines with a single article were pooled, for a total of $(26 \%)$ of publications (Table 1).

Regarding the group of participants investigated in the studies, mostly were concentrated in the el-
Table 1. Distribution of number of articles published by journals in the period 2011 to 2015.

\begin{tabular}{l|c|c|}
\hline \multicolumn{1}{|c|}{ Journals } & N & $\%$ \\
\hline Rev. bras. geriatr. gerontol. & 10 & 20 \\
\hline Ciência \& Saúde Coletiva & 9 & 18 \\
\hline $\begin{array}{l}\text { J. res. fundam. care. Online } \\
\text { Rev enferm UERJ }\end{array}$ & 5 & 10 \\
\hline Cad. Saúde Pública & 4 & 8 \\
\hline Rev Saúde Pública & 3 & 6 \\
\hline Rev Gaúcha Enferm & 2 & 4 \\
\hline $\begin{array}{l}\text { Psicologia: Reflexão e Crítica } \\
\text { Others: Rev Bras Clin Med.; Rev assoc med bras; }\end{array}$ & 2 & 4 \\
\hline Hospital Israelita Albert Einstein - HIAE; Elsevier & 2 & 4 \\
\hline $\begin{array}{l}\text { Editora Ltda; Texto contexto - enferm; Rev Bras } \\
\text { Ativ Fis e Saúde; Kairós Gerontologia; Rev Esc } \\
\text { Enferm USP; Rev Med Minas Gerais; Dement. }\end{array}$ & 13 & 26 \\
\hline $\begin{array}{l}\text { Neuropsychol; Esc Anna Nery; Revista Baiana de } \\
\text { Saúde Pública. (1 para cada) }\end{array}$ \\
\hline \begin{tabular}{l} 
Total Source: Research data \\
\hline
\end{tabular}
\end{tabular}

derly; review articles were classified as "not applicable"; other studies involved other participants, although the subject investigated indirectly understood aspects of aging and inherent chronicity in elderly people (Table 2).

Table 2. Distribution of participant groups of research on articles published in the period 2011-2015.

\begin{tabular}{|l|c|c|}
\hline \multicolumn{1}{|c|}{ Journals } & N & $\%$ \\
\hline Elderly & 32 & 64 \\
\hline Not applicable & 10 & 20 \\
\hline $\begin{array}{l}\text { Others: Health community agents; professors } \\
\text { and academic of nursing; adults; health } \\
\text { professionals and family members; managers } \\
\text { and professionals in health; research groups; } \\
\text { players of Mahjong and Gateball; students of } \\
\text { open university for elderly .(one for each) }\end{array}$ & 08 & 16 \\
\hline $\begin{array}{l}\text { Total } \\
\text { Tource: Research data }\end{array}$ \\
\hline
\end{tabular}

Regarding the bond regions of the first author of the article and the publication of regions, it was observed in both cases the highest concentration is 
in the Southeast, followed by the South and Northeast. Among the states highlights were the states of São Paulo and Rio Grande do Sul (Table 3).

Table 3. Percentage distribution of the state and region most represented on published articles and the first author link in the period 2011-2015.

\begin{tabular}{|l|c|c|}
\hline \multicolumn{1}{|c|}{ State/Region collection } & N & $\%$ \\
\hline São Paulo-SE & 13 & 26 \\
\hline Rio Grande do Sul-S & 8 & 16 \\
\hline Minas Gerais-SE & 7 & 14 \\
\hline Rio de Janeiro-SE & 6 & 12 \\
\hline Santa Catarina-S & 5 & 10 \\
\hline Bahia-NE & 3 & 6 \\
\hline Alagoas-NE & 2 & 4 \\
\hline Distrito Federal-CO & 1 & 2 \\
\hline Espírito Santo-SE & 1 & 2 \\
\hline Goiás-CO & 1 & 2 \\
\hline Paraíba-NE & 1 & 2 \\
\hline Rio Grande do Norte-NE & 1 & 2 \\
\hline Tocantins-N & 1 & 2 \\
\hline São Paulo-SE & 12 & 24 \\
\hline Rio Grande do Sul-S & 10 & 20 \\
\hline Minas Gerais-SE & 7 & 14 \\
\hline Rio de Janeiro-SE & 5 & 10 \\
\hline Não se aplica & 4 & 8 \\
\hline Alagoas-NE & 2 & 4 \\
\hline Bahia-NE & 2 & 4 \\
\hline Santa Catarina-S & 2 & 4 \\
\hline Rio Grande do Norte-NE & 1 & 2 \\
\hline Maranhão-NE & 1 & 2 \\
\hline Espíruto Santo-SE & 1 & 2 \\
\hline Paraíba-NE & 1 & 2 \\
\hline Goiás-CO & 1 & 2 \\
\hline Distrito Federal-CO & 1 & 2 \\
\hline Total & 50 & 100 \\
\hline & Source: & Research \\
\hline
\end{tabular}

\section{Discussion}

Regarding the period of publication, 2011 was a year of great relevance for the topic, with the convening of the High Level Meeting of the United
Nations for chronic non-communicable diseases (NCDs). Among the main results of this meeting, signed up a global commitment between countries and gave the referral to the approval, in 2013, during the 65th World Health Assembly, of the 2015-2025 voluntary targets for the prevention and control of non-communicable diseases and NCDs Global Plan. It is clear, therefore the impact of these strategies in the academic world, prompting the rise of the scope of research relating to this subject. [11]

Regarding the noticeable recovery in the thematic approach after 2014, it is worth highlight the arrival of ordinance No. 483, April 1 2014, redefining the People Health Attention Network with Chronic Diseases in the Unified Health System (Sistema Único de Saúde: SUS) and establishing guidelines for the organization of their care lines, though still there is the need for approaches about the current state of health strategies focused on chronic diseases, especially in relation to the elderly. [12]

It is noteworthy, in general, the significant scientific approach about chronic diseases related to the elderly at all levels of knowledge evidenced in the degree of the first author of the articles analyzed, demonstrating that there is awareness of the academic community on issues of emerging pubic policies.

It is considered that the high number of professional with master's degrees or Ph.D.s identified in this study is related to the increased supply of postgraduate courses in stricto sensu modality in the past two decades, with one of its main objectives the training of researchers able to develop scientific research. The significant number of researchers with a Ph.D degree on this study is consistent with previous studies demonstrating the growth and consolidation of graduate programs, while highlighting the increase in Brazilian scientific productivity with issues related to the elderly. $[13,10]$

Regarding the mode of the articles, the Technical Standards Association defines original article as part 
of a publication that presents topics or original approaches relating to research, indicating conclusive and significant results, while the review article of a publication summarizes, analyzes and discusses information already published. So the original articles are considered primary sources of original knowledge of the authors and the review articles are considered secondary sources, as they cited, review and interpret original works. [14, 15]

It is important to note that both types of articles are fundamental to scientific research, but with distinct styles in the research. It is noteworthy a significant quantity of original articles in this study, which allows new relevant knowledge on chronic diseases related to the elderly in scientific production.

The chronicity and aging relationship is a public health problem today, raising trends for research on this topic in Brazil in recent decades. Research shows that chronic diseases cause approximately $74 \%$ of deaths in Brazil due to population aging, so in this scenario Brazil developed in 2011 the Strategic Action Plan for tackling NCDs 2011-2022. In this context it was set the Health Attention Network for those users within the Unified Health System (Sistema Único de Saúde: SUS), through Ordinance No. 483, April 1, 2014, which ensures the Brazilian qualified service and coordinated between all health care units. [16, 17]

It is observed that there is relevant scientific literature on the topic; however, it identifies a few studies that reports results previously analyzed about this context. It is also noteworthy that the Unified Health System (Sistema Único de Saúde: SUS), has provided connection with the academic community, collaborating with the extension and accessible technical resources, mainly favoring evaluating public policies and programs. [18]

It is noteworthy that even in a lesser percentage, areas of knowledge in health and nutrition, physiotherapy, among others, demonstrate adherence to this theme, showing the interest of researchers to disseminate their studies related to the elderly and chronic diseases, further increasing the scope of publications in national and international circulation journals.

It is noticed that the scientific production of geriatric nursing is growing apace, certainly in an attempt to meet the health care demands of the emerging population group of elderly seen in recent years, in Brazil and other countries. A previous study, with approach in the elderly, was in line with that presenting predominance of authors in the areas of multi-disciplinary knowledge, medicine and nursing, reinforcing that these areas are highlighted in the scientific research of this topic. [10]

It is evident a progress about interdisciplinarity on the selected theme, greatly contributing to a new concept of multi-disciplinary knowledge, defined as content produced by a multidisciplinary team, that is, with the participation of at least two professionals from different areas of knowledge in the preparation of the publication, which generates greater scientific contribution among professionals. [13]

We emphasize the importance of understanding by health professionals, in different fields, of the valuation of the changes through the course of life, and how these affect the daily life or the healthdisease process on people, in order to modify and create coping strategies in certain situations of chronicity on aging. [19]

The questionnaire, instrument of choice for some of the studies, is the research technique consists of questions submitted in writing to people, having as objective the knowledge of opinions, beliefs, feelings, interests, expectations, situations experienced, while the interview is the technique in which researchers introduce themselves to the people researched formulating questions, with the aim of obtaining data of interest to the research. Both collaborate to seizure of relevant data in the research of chronic diseases in specific populations such as the elderly, supporting the qualitative and/ or quantitative research. [20]

Brazil is responding to the challenge represented by chronic diseases, therefore, in 2005, the Department of Health and Department of Scien- 
ce and Technology issued a notice for financing studies related to chronic diseases, whose research instruments were based on questionnaires and interviews. [18]

It is appropriate to emphasize the Free Association Test Words (TALP) as collection technique that can work in accordance with certain objects of research to better data extraction when the research refers to cognitive and social processes of the subjects involved, widely used in studies of social representations of health research. Studies using TALP report the association between the stimulus association of chronic disease to feelings of sadness, pain, remedy, situations of difficulty, learning, lack of healing, need for care, and emphasize the importance of this technique in the collection of subjectivities related the difficulties and limitations arising from the disease itself. [21, 22, 23]

It is also worth mentioning the Census as a set of statistics from the Brazilian Institute of Geography and Statistics (IBGE), which tells different characteristics of the inhabitants of a city, a state or a nation. In 2013, IBGE published a thematic issue bringing a sampling plan and comments on issues related to the health conditions of the population, focusing on perception of chronic diseases. This instrument provides data to the Department of Health expanding considerably the knowledge about the health characteristics of the population, offering to the executive and legislative bodies, professionals and researchers, the Health Councils and other actors interested in the topic a wide range of information necessary for the formulation, monitoring and evaluation of health policies. [24]

Analyzing the form and impact of disclosures, it is assumed that the articles in the study have achieved publications in journals considered with satisfactory circulation and geographic scope, as when analyzing the Qualis/Capes, a type of stratification quality of scientific journals, the selected articles found themselves, mostly in the strata B1 and B2.

It is inferred that the demands inherent in the aging process are essential to the production of knowledge in the areas of Geriatrics and Gerontology and the public health, and it is appropriate that these journals show higher numbers of publications. Thus, research in this area has been used as an instrument of reasoning in science, to clarify, seek understanding and problem solving related to the elderly, including chronic diseases. [13]

It emphasizes the modest scientific production in various journals appointed, with just one article in this study. By the epidemiological profile and alarming national sociodemographic, it emphasizes the weaknesses in research to elderly people, often little fomented among some segments of researchers, including newspapers on the geriatrics and gerontology area such as Magazine Kairos Gerontology, Geriatrics \& Gerontology, Interdisciplinary Studies on Aging, Dementia \& Neuropsychologia.

However, it is noticed a growth in publications about the process health/disease of the elderly, in recent years, punctuating chronic diseases with a different view in the context of social and health policies, focused on the Brazilian population. It was attributed to this the rise in the number of magazines and national issues and study funding possibilities, as well as the increase of public policies focused on the elderly. $[25,13]$

The predominant age group of elderly participants in the research for this study has not been researched in the articles, but was established criterion of 60 or more to their inclusion in the participant sample group of articles. Currently, several studies show the elderly as a research subject, especially when the issues investigated are related to this population and it was observed that when it comes to reviews, the filter "elderly" is used to direct the studies to this specific population. [26]

It is related to the gain of more space in the scientific community, the approaches to aging and inherent pathological changes to elderly people to the increase of population of this age group in recent years, entering as current researched group participant and emerging in the various areas discussions research and publication. [27] 
It is important to emphasize that the elderly population is the most affected by chronic diseases, which explains the predominance of studies that choose to elect the elderly as researched subjects. It is emphasized that chronic diseases related to the elderly require a comprehensive public health response, however, the debate has been insufficient and the evidence of what can be done, are limited. In this sense, the policies directed to the elderly should be built on a fundamental change in our understanding of aging, considering all aspects of the diversity of populations and inequalities that often underlie, requiring use better ways to measure and monitor the health and functioning of this population. [28]

It is worth emphasizing that in Brazil, the Health Coordination of the Elderly/DAET/SAS has established among its priorities for the years 2013/2014, the preparation and dissemination of the Comprehensive Model Plan of Health Care for Elderly, integrated with Care Health Networks, ordered by primary care entering the Strategic Action Plan for the Fight of Chronic Non-communicable Disease, but in practice, there is still a lot to accomplish. [29]

The aging index (El) is defined as the number of people over 60 years old, for every 100 children under 15 years old, of the resident population in a given geographical area. 30 In Census released in April 2011, the El on the states of São Paulo and Rio Grande do Sul was higher than the global aging index in Brazil. [31]

A milestone occurred in 1982 with the World Assembly on Ageing, where the International Plan of Action of Vienna was approved, which led to important reflection on the impact of this issue in developing countries like Brazil and consequently, the Brazilian states, such as São Paulo, to increase programs for this population. [32]

In the state of São Paulo and in a study conducted in Rio Grande do Sul, the explanatory element to justify this episode certainly is the impact of graduate programs studying human aging in master's and doctoral level, where there is a diversity of areas with multidisciplinary research groups and many of its researchers linked to health. [33] Institutions that conducted more researches related to aging are located in the South, with the exception of the Federal University of Rio Grande do Norte, in the Northeast. [34]

Another relevant factor was the creation of postgraduate courses dealing with the topic. The Pontifical Catholic University of São Paulo (PUC/SP) was the pioneer in this state, with the design of the Master's Program in Gerontology, being a multidisciplinary course, created in 1997. Another university highlighted is the State University of Campinas (Unicamp), which established its Master's courses in 2008 and PhD in 2010, also in Gerontology. 35 Still, have been created other Masters courses in gerontology, like the first Professional Master's in Gerontology of the Federal University of Paraíba linked to the Health Sciences Centre (Centro de Ciências da Saúde: CCS).

Thus, it is observed that the present study shows similarity with data obtained previously, in which the Southeast, followed by the South and Northeast have shown higher concentration with respect to the region of collection and the bond of the first author, and with São Paulo and Rio Grande do Sul having the highest percentage.

\section{Conclusions}

The results will help to identify the scientific production about the chronic diseases related to the elderly in the context of the last five years. It is important to point out some difficulties and limitations, such as: in some articles the academic degree of the author was not contained on the title page, it was observed that most of the articles contained two descriptors or at most three, and when the instrument used was the questionnaire was difficult identifying the data analysis used. Therefore, we would like to suggestion such observations, to encourage further studies and facilitate the search on the topic.

It is emphasized that the scientific production about the chronic diseases related to the elderly in 
Brazil is still incipient, suggesting the need for further research, particularly in the context of health promotion and prevention of disabilities.

Thus, we can conclude that this promising trend of publications in Brazil has a fundamental importance because the population has a rapidly aging, increasing life expectancy and the rise of chronic non-communicable diseases. Therefore, it is necessary that studies with data on scientific production in the area allow guidance to managers, health professionals and other stakeholders.

\section{Authors' contributions}

TNS has worked in the stages of preparation of the article, from conception, design, developing bank data, analysis and interpretation of data, manuscript drafting and develop of the conceptual map. AMSF contributed in the design, development, design, database construction, analysis and interpretation of data and writing. MGDM contributed in the design, database develop, analysis and interpretation of data and writing. MLAG contributed in the design, database develop, analysis and interpretation of data and writing. AKMV and AZVMF contributed on analysis of data and writing. AKFJA held orientation of the manuscript and critical review. GKGDB, VPB and MASPM made critical reading of the manuscript and general suggestions. AOS held the approval of the final version to be published.

\section{Conflicts of interest}

The authors declare no conflict of interest.

\section{References}

1. Saintrain MVL, Gondim APS, Silva VTBL. O Sistema Único de Saúde cuidando da pessoa idosa. Fortaleza: EDUECE; 2014. 352 p.

2. Küchemann BA. Envelhecimento populacional, cuidado e cidadania: velhos dilemas e novos desafios. Revista Sociedade e Estado. 2012 Jan/Abril; 27(1): 165-167.

3. PAHO. Pan American Health Organization/World Health Organization (WHO). Improving Chronic Illness Care through
Integrated Health Service Delivery Networks. Washington, D.C.: OPS; 2012. $44 p$

4. Mendes EV. As redes de atenção à saúde./Eugênio Vilaça Mendes. Brasília: Organização Pan-Americana da Saúde; 2011. 549 p.

5. Brasil. Ministério da Saúde. Secretaria de Atenção à Saúde. Departamento de Atenção Básica. Diretrizes para o cuidado das pessoas com doenças crônicas nas redes de atenção à saúde e nas linhas de cuidado prioritárias/Ministério da Saúde, Secretaria de Atenção à Saúde, Departamento de Atenção Básica. - Brasília: Ministério da Saúde; 2013. 28 p.

6. Silveira RE, Silva Santos Á, Sousa MC, Monteiro TSA. Gastos relacionados a hospitalizações de idosos no Brasil: perspectivas de uma década. Einstein. 2013; 11(4): 514-20.

7. Moraes EN. Atenção à saúde do Idoso: Aspectos Conceituais. Brasília: Organização Pan-Americana da Saúde; 2012. 98 p.

8. Araujo RF, Alvarenga L. A bibliometria na pesquisa científica da pós-graduação brasileira de 1987 a 2007. Enc. Bibli: R. Eletr. Bibliotecon. Ci. Inf., 2011, Florianópolis; 16(31):51-70.

9. Medeiros JMG, Vitoriano MAV. A evolução da bibliometria e sua interdisciplinaridade na produção científica brasileira. Rev. Digit. Bibliotecon. Cienc. Inf. 2015 Set/Dez;13(3): 491-503.

10. Duarte MCS, Costa SFGD, Morais GSDN, França JRFDS, Fernandes MA, Lopes MEL. Produção científica sobre a pessoa idosa em cuidados paliativos: estudo bibliométrico. Rev. pesqui. cuid. fundam.(Online), 2015 7(3): 3093-3109. [Acesso em junho 2016]; Disponível a partir de: http://www.index-f.com/ pesquisa/2015/r73093.php

11. Malta DC, Silva Jr JBD. Plano de Ações Estratégicas para o Enfrentamento das Doenças Crônicas Não Transmissíveis no Brasil após três anos de implantação, 2011-2013. Epidemiologia e Serviços de Saúde. 2014 23(3): 389-395.

12. Brasil. Ministério da Saúde. Portaria $n^{\circ} 483$, de $1^{\circ}$ de abril de 2014. [Acesso em maio 2016]; Disponível a partir de: http://bvsms. saude.gov.br/bvs/saudelegis/gm/2014/prt0483 01042014. $\underline{\text { html. }}$.

13. Medeiros KKAS, Costa GMC, Coura AS, Araújo AKF, Celino SDDM. Perfil bibliométrico da produção científica (inter) nacional da Enfermagem Gerontogeriátrica. Rev. bras. geriatr. Gerontol. 2014 17(2): 425-438.

14. ABNT. Associação brasileira de normas técnicas. nbr 6022: informação e documentação - artigo em publicação periódica científica impressa - apresentação. Rio de Janeiro: ABNT; 2003, 2 p.

15. Pizanni L, Silva RC, et al. A arte da pesquisa bibliográfica na busca do conhecimento, Rev. Dig. Bibl. Ci. Inf., Campinas. 2012; jul./dez; 10 (1): 53-66.

16. Fonseca A. Coelho da O cuidado integrado no sistema de saúde suplementar no Brasil: um modelo de atenção à saúde para o idoso portador de doenças crônicas./Anelise Coelho da Fonseca. -2015. Tese (Doutorado)- Escola Nacional de Saúde Pública Sergio Arouca, Rio de Janeiro, 2015. 156 p. 
17. Brasil, Ministério da Saúde. Secretaria de Vigilância em Saúde. Departamento de Análise de Situação de Saúde. Plano de Ações Estratégicas para o Enfrentamento das Doenças Crônicas Não Transmissíveis (DCNT) no Brasil 2011-2022. Brasília: Ministério da Saúde; 2011. 160 p.

18. Ducam BB, et al. Doenças Crônicas Não Transmissíveis no Brasil: prioridade para enfrentamento e investigação, 2012. Rev Saúde Pública. 2012; 46(Supl): 26-34.

19. Silva LM, et al. Mudanças e acontecimentos ao longo da vida: um estudo comparativo entre grupos de idosos. Rev. LatinoAm. Enfermagem. 2015; Jan/Fev; 23(1): 3-10.

20. GIL, AC. Métodos e técnicas de pesquisa social/Antônio Carlos Gil. - 6. ed. - São Paulo: Atlas; 2008, 200 p.

21. Tavares DWS, et al. Protocolo verbal e teste de associação livre de palavras: perspectivas de instrumentos de pesquisa introspectiva e projetiva na ciência da informação. Ponto de acesso [Internet]. 2014; 8 (3): 64-79. [Acesso em junho 2016]; Disponível a partir de: http://www.portalseer.ufba.br/index. php/revistaici/article/viewArticle/12917

22. Marcolino $A B L$, et al. The Theory of Social Representations in Brazilian Health Researches: a Bibliometric Profile. Internatlonal archlves ofMedlcIne sectlon: Psychology. 2016 9(82): 1-9.

23. Resende OLC, et al. A representação do adoecer em adolescentes com lúpus eritematoso sistêmico. Rev Bras Reumatol. (online) 2016. [Acesso em 15 junho]; disponível a partir: http://dx.doi. org/10.1016/j.rbr.2016.02.004

24. IBGE. Pesquisa nacional de saúde: 2013. Percepção do estado de saúde, estilos de vida e doenças crônicas: Brasil, grandes regiões e unidades da federação Rio de Janeiro: IBGE; 2014, $180 \mathrm{p}$.

25. Cabral, RWL, Santos, SR, Menezes, KDNB, Albuquerque, AV, Medeiros, AL. Fatores sociais e melhoria da qualidade de vida dos idosos: revisão sistemática. Rev Enferm UFPE. 2013 7(5): 1434-42.

26. Rebellato C, Hayashi MCPI. Participação social do idoso: estudo bibliométrico da produção científica recente (2010-2013). RECIIS - Rev. Eletron. de Comun. Inf. Inov. Saúde. 2014 set.; 8(3): 264287.

27. Ceccon FG. Estudo bibliométrico da produção nacional da pósgraduação acerca do controle postural em idosos. Biblioteca Lascasas, 2014; 10(3):1-7.

28. OMS. Organização Mundial da Saúde. Relatório mundial de envelhecimento e saúde. Printed in the United States of America, 2015. [Acesso em junho 2016]; Disponível a partir de: http://sbgg.org.br/wp-content/uploads/2015/10/OMSenvelhecimento-2015-port.pdf.

29. Brasil. Ministério da Saúde. Diretrizes para o cuidado das pessoas idosas no SUS: proposta de modelo de atenção integral. XXX congresso nacional de secretarias municipais de saúde. Brasília, All Type Assessoria Editorial Ltda; 2014. 46 p.
30. Rede Internacional de Informações para a saúde (RIPSA). Departamento de Informática do SUS/Ministério da Saúde (DATASUS). Características dos indicadores - Fichas de qualificação, 2009. [Acesso em junho 2016]; Disponível em: http://www.ripsa.org.br/.

31. IBGE. Instituto Brasileiro de Geografia e Estatística. Censo 2010. [Acesso em maio 2016]; Disponível a partir de: http://censo2010. ibge.gov.br/

32. Kletemberg, D. F.; et al. A construção histórica do conhecimento da enfermagem gerontológica no Brasil. Revista de Enfermagem, Rio de Janeiro, 14(4): 787-796, out./dez. 2010.

33. Pedroso, A. A. A pesquisa sobre envelhecimento humano: grupos de pesquisa no estado de São Paulo. RBCEH, Passo Fundo, 10(1): 92-103, jan./abr. 2013.

34. Chena, D. N. C.; et al. Envelhecimento e interdisciplinaridade: análise da produção científica da Revista Estudos Interdisciplinares Sobre O Envelhecimento. Estudos Interdisciplinares Envelhecimento, Porto Alegre, 20(3): 883-901, 2015.

35. CNPq. Conselho Nacional de Desenvolvimento Científico e Tecnológico. Diretório dos Grupos de Pesquisa do Brasil [portal na Internet] 2012. [Acesso em junho 2016] Disponível em: www. cnpq.br.

\section{Publish in International Archives of Medicine}

International Archives of Medicine is an open access journal publishing articles encompassing all aspects of medical science and clinical practice. IAM is considered a megajournal with independent sections on all areas of medicine. IAM is a really international journal with authors and board members from all around the world. The journal is widely indexed and classified Q2 in category Medicine. 